\title{
HIV/HCV Co-infection: Pathogenesis, Clinical Complications, Treatment, and New Therapeutic Technologies
}

\author{
Eva A. Operskalski • Andrea Kovacs
}

Published online: 11 January 2011

(C) The Author(s) 2011. This article is published with open access at Springerlink.com

\begin{abstract}
World-wide, hepatitis C virus (HCV) accounts for approximately 130 million chronic infections, with an overall $3 \%$ prevalence. Four to 5 million persons are coinfected with HIV. It is well established that HIV has a negative impact on the natural history of $\mathrm{HCV}$, including a higher rate of viral persistence, increased viral load, and more rapid progression to fibrosis, end-stage liver disease, and death. Whether HCV has a negative impact on HIV disease progression continues to be debated. However, following the introduction of effective combination antiretroviral therapy, the survival of coinfected individuals has significantly improved and $\mathrm{HCV}$-associated diseases have emerged as the most important co-morbidities. In this review, we summarize the newest studies regarding the pathogenesis of HIV/HCV coinfection, including effects of coinfection on HIV disease progression, HCV-associated liver disease, the immune system, kidney and cardiovascular disease, and neurologic status; and effectiveness of current anti-HIV and HCV therapies and proposed new treatment strategies.
\end{abstract}

Keywords HIV/HCV coinfection - HIV/HCV progression . $\mathrm{HIV} / \mathrm{HCV}$ treatment guidelines $\cdot \mathrm{HIV} / \mathrm{HCV}$ pathogenesis . $\mathrm{HIV} / \mathrm{HCV}$ immunopathogenesis $\cdot \mathrm{HIV} / \mathrm{HCV}$ comorbidities

E. A. Operskalski $(\bowtie) \cdot$ A. Kovacs

Maternal Child and Adolescent Center for Infectious Diseases and Virology, Department of Pediatrics, Keck School of Medicine, University of Southern California,

1640 Marengo Street, HRA 300,

Los Angeles, CA 90033, USA

e-mail: eva@usc.edu

A. Kovacs

e-mail: akovacs@usc.edu

\section{Introduction}

Worldwide, there are an estimated 130 million chronic hepatitis $\mathrm{C}$ virus (HCV) infections, with an overall prevalence of $3 \%$. Approximately 4 to 5 million persons are co-infected with HIV. In the US and Western Europe, among HIV-infected persons, HCV prevalence is $72 \%$ to $95 \%$ among injection drug users (IDU), $1 \%$ to $12 \%$ in men who have sex with men (MSM), and $9 \%$ to $27 \%$ in heterosexuals [1]. After acute infection, $15 \%$ to $45 \%$ clear the virus, and $20 \%$ to $30 \%$ with persistent viremia develop liver fibrosis, and potentially cirrhosis, liver failure, and hepatocellular carcinoma [2]. Transmission is primarily through IDU or transfusion of infected blood or blood products, although sexual transmission has been suggested among HIV-infected women and documented among MSM [3-5].

$\mathrm{HCV}$ is an enveloped positive-strand RNA virus with six genotypes. Genotype 1 predominates in North America [6] and is associated with higher HCV RNA levels [7]. Replication occurs primarily in hepatocytes but also in extrahepatic reservoirs, including PBMCs, in patients with HIV [8].

Recent reviews have discussed many aspects of coinfection, including new noninvasive methods for assessing liver fibrosis $[9,10]$, current anti-HCV treatment regimens [11-13], novel agents and therapeutic strategies [12, 14, 15•], virologic and immunologic features in pathogenesis [16-19], and clinical outcomes [16, 20, 21]. In this review, we summarize other studies providing new information regarding $\mathrm{HIV} / \mathrm{HCV}$ coinfection.

\section{Overview}

The pathogenesis of HIV and HCV disease progression, including immune system dysfunction and clinical compli- 
cations in the setting of coinfection, are summarized in Fig. 1 and described below.

\section{HIV Disease Progression in the Setting of HCV Co-infection}

Although most studies demonstrate increased mortality among co-infected individuals, a recent meta-analysis of over 30 studies with over 100,000 patients found no increase in mortality in co-infected patients in the preHAART era. Post-HAART, co-infection increased risk of overall mortality but not of AIDS-defining conditions [22]. In contrast, an Italian cohort study found a twofold increased AIDS risk among co-infected patients [23]. The Women's Interagency HIV Study (WIHS) found an almost twofold increased AIDS risk among co-infected women without a CD4 count $<200$ cells $/ \mu \mathrm{L}$ and for ART-naïve women [24••]. The Italian cohort showed increases in bacterial and mycotic infections and WIHS found increases in bacterial pneumonia, HIV encephalopathy, and wasting syndrome, suggesting the need for earlier and more aggressive HIV and HCV treatment in co-infected individuals $[23,24 \bullet \bullet]$.

Recent studies found high levels of T-cell activation in co-infected compared to HIV monoinfected individuals even following HAART [24••, 25, 26]. Chronic immune activation may lead to immune dysfunction and cytokine production, causing enhanced HIV and HCV replication and lower T-cell counts [25]. The WIHS study showed that high levels of activated CD8 T cells are associated with incident AIDS among HCV-viremic women but not HCVuninfected women, and CD4 activation predicted AIDS in both groups $[24 \bullet \bullet, 25]$. Suppression of HCV with therapy reduces activation [26]. These results again support early treatment of HIV and HCV.

Several pathways for active HCV infection impacting HIV infection have been proposed (Table 1). HCV coinfection may increase immune activation, leading to $\mathrm{CD} 4$ T-cell apoptosis in HIV-untreated patients and more rapid

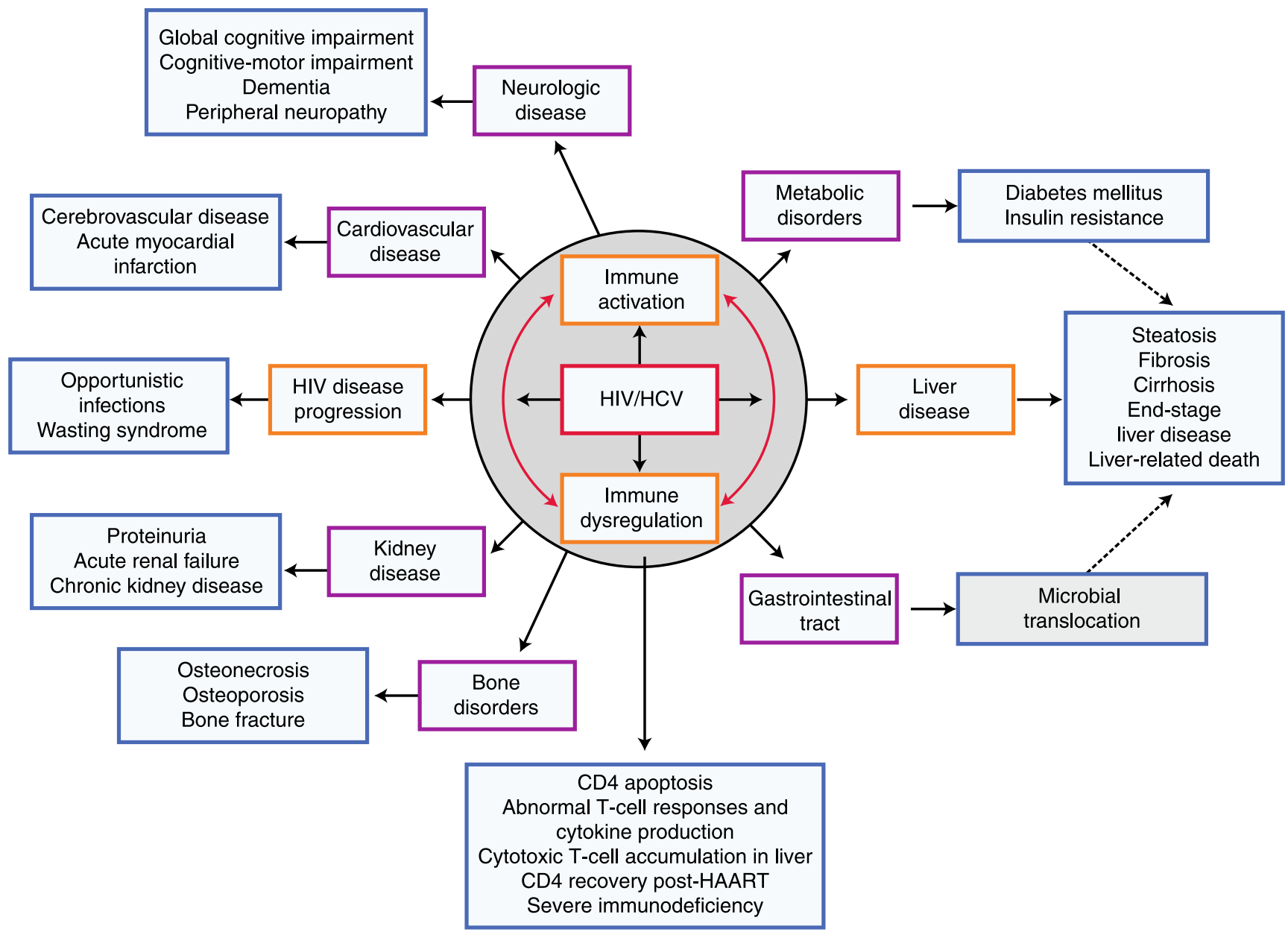

Fig. 1 Pathogenesis of HIV/HCV co-infection: Immune activation and dysregulation, effects on HIV and HCV disease progression, and complications in multiple organ systems 
Table 1 Pathogenesis of HIV/HCV-associated diseases and complications

\begin{tabular}{|c|c|c|c|}
\hline $\begin{array}{l}\text { Affected organ/ } \\
\text { system }\end{array}$ & Complication & Proposed mechanism of action & References \\
\hline \multirow[t]{5}{*}{ Immune } & \multirow[t]{3}{*}{$\begin{array}{l}\uparrow \text { HIV disease } \\
\text { progression }\end{array}$} & $\begin{array}{l}\uparrow \mathrm{CD} 4 \text { and CD8 T-cell activation, leading to } \uparrow \text { immune dysfunction } \\
\text { and cytokine production, enhanced HIV and HCV production, } \\
\text { and } \downarrow \text { T-cell counts }\end{array}$ & {$[24 \bullet \bullet, 25,26]$} \\
\hline & & $\begin{array}{l}\text { HCV-induced } \uparrow \text { CD4 T-cell apoptosis, leading to severe } \\
\text { immunodeficiency }\end{array}$ & {$[27]$} \\
\hline & & HCV-induced $\downarrow$ CD4 recovery post-HAART & [28] \\
\hline & $\uparrow$ Cryoglobulinemia & $\uparrow$ Cryoglobulin production by activated B cells & [53] \\
\hline & $\begin{array}{l}\downarrow \text { CRP production } \\
\text { in liver }\end{array}$ & Unknown & [54] \\
\hline \multirow[t]{10}{*}{ Liver } & $\uparrow$ Steatosis & $\begin{array}{l}\text { HIV-related mitochondrial translocation ( } \uparrow \text { LPS)-induced } \\
\text { immune activation }\end{array}$ & {$[16,18,26,42]$} \\
\hline & $\uparrow$ Fibrosis & $\uparrow$ Activation of CD4 and CD8 T cells & {$[26]$} \\
\hline & $\uparrow$ Cirrhosis & $\begin{array}{l}\uparrow \text { Levels of cytokines (eg, IL-4, IL-5, IL-13, TGF- } \beta \text {, IFN- } \gamma \\
\text { and TNF- } \alpha \text { ) and chemokines (eg, IP-10 and IL- } 8 \text { ) }\end{array}$ & {$[17,18]$} \\
\hline & $\uparrow$ ESLD & HIV-induced $\downarrow$ HCV-specific CD4 and CD8 T-cell responses & {$[16,17]$} \\
\hline & \multirow[t]{6}{*}{$\uparrow \mathrm{HCC}$} & $\uparrow$ Levels of cytotoxic CD8 T cells in liver & {$[39,40]$} \\
\hline & & $\uparrow$ Activation of HSC & {$[18,19,43]$} \\
\hline & & $\uparrow$ Apoptosis of hepatocytes and HSC, mediated by TRAIL & {$[16-19,44]$} \\
\hline & & $\uparrow$ Collagen synthesis by HIV-infected HSC & [43] \\
\hline & & $\uparrow$ HSC production of collagen by HIV-infected Kupffer cells & {$[16]$} \\
\hline & & $\begin{array}{l}\text { Insulin resistance-associated hyperinsulinemia and } \\
\text { hyperglycemia stimulate HSC to } \uparrow \text { connective tissue } \\
\text { growth factor and extracellular matrix }\end{array}$ & {$[45,46]$} \\
\hline \multirow[t]{2}{*}{ Liver/metabolic } & Diabetes mellitus & Unknown & {$[68]$} \\
\hline & \multirow[t]{2}{*}{ Insulin resistance } & Unknown & [46] \\
\hline Cardiovascular & & $\begin{array}{l}\text { HIV- and HCV-associated chronic inflammation leads to } \\
\text { endothelial dysfunction, causing } \uparrow \text { sCAMS }\end{array}$ & {$[59,60]$} \\
\hline \multirow[t]{2}{*}{ Hematologic } & \multirow[t]{2}{*}{ Thrombocytopenia } & Sequestration of platelets in cirrhosis and portal hypertension & {$[55]$} \\
\hline & & $\downarrow$ Production of thrombopoietin in advanced liver disease & {$[55]$} \\
\hline \multirow[t]{4}{*}{ Kidney } & Proteinuria & Unknown & {$[56]$} \\
\hline & $\begin{array}{l}\text { Acute interstitial nephritis } \\
\text { Acute tubular necrosis }\end{array}$ & Unknown & {$[58]$} \\
\hline & $\begin{array}{l}\text { MPGN } \\
\text { Acute renal failure }\end{array}$ & $\begin{array}{l}\text { Stimulation of B cells to } \uparrow \text { cryoglobulin production and } \\
\text { deposits in renal vessels }\end{array}$ & {$[53,56-58]$} \\
\hline & \multicolumn{3}{|l|}{ Chronic kidney disease } \\
\hline Gastrointestinal & $\begin{array}{l}\text { Mitochondrial } \\
\text { translocation }\end{array}$ & $\begin{array}{l}\text { HIV-inducted } \uparrow \text { gut permeability and depletion of CD4 cells } \\
\text { from gut-associated lymphoid tissue }\end{array}$ & {$[16]$} \\
\hline \multirow[t]{3}{*}{$\begin{array}{l}\text { Central/peripheral } \\
\text { nervous }\end{array}$} & $\begin{array}{l}\text { Neurocognitive } \\
\text { syndromes }\end{array}$ & HIV and HCV replication in brain & {$[61]$} \\
\hline & \multirow[t]{2}{*}{$\begin{array}{l}\text { Peripheral neuropathy } \\
\text { syndromes }\end{array}$} & $\begin{array}{l}\mathrm{HCV} \text { core protein activates glia and } \uparrow \mathrm{HIV} \text {-associated } \\
\text { neurotoxicity }\end{array}$ & {$[62]$} \\
\hline & & $\begin{array}{l}\text { LPS-induced monocyte activation and } \uparrow \mathrm{HIV} \text {-associated } \\
\text { dementia }\end{array}$ & {$[65]$} \\
\hline Bone & $\begin{array}{l}\text { Osteoporosis } \\
\text { Osteonecrosis }\end{array}$ & $\downarrow$ Bone mass in chronic liver disease & {$[70]$} \\
\hline
\end{tabular}

CRP C-reactive protein; ESLD end-stage liver disease; HCC hepatocellular carcinoma; HSC hepatic stellate cells; LEE liver enzyme elevations; LPS lipopolysaccharides; MPGN membranoproliferative glomerulonephritis; $s C A M S$, soluble cellular adhesion molecules; TRAIL, tumor necrosis factor-related apoptosis-inducing ligand

progression to severe immunodeficiency [27]. However, the impact of $\mathrm{HCV}$ infection on CD4 cell recovery following HAART is conflicting; some reports note a poorer CD4 response in co-infected compared to monoinfected patients [28], and others do not [27, 29-31].

\section{HCV-Associated Liver Disease Progression in the Setting of HIV Co-infection}

Despite reductions of morbidity and mortality in HIVinfected individuals on HAART, liver-related deaths now 
represent a leading cause of death in this population, primarily due to $\mathrm{HCV}$ co-infection. $\mathrm{HCV}$-associated liver disease, including fibrosis, cirrhosis, and end-stage liver disease (ESLD), is accelerated in HIV-infected individuals. Progression to cirrhosis is threefold higher in co-infected than monoinfected patients, and approximately $33 \%$ progress to cirrhosis in less than 20 years [32••]. A recent metaanalysis of 17 studies found cirrhosis in $21 \%$ of 3567 coinfected individuals after 20 years of infection and $49 \%$ after 30 years [33]. Another meta-analysis of 27 studies among 7666 individuals found that co-infected individuals had a twofold increased rate of cirrhosis compared to monoinfected [33]. Severe liver fibrosis and cirrhosis were also found in $10 \%$ to $25 \%$ of co-infected $\mathrm{HCV}$ viremic patients with normal alanine aminotransferase (ALT) levels $[34,35]$. A 20 -year prospective study found increased risk of hepatitis/liver-related deaths despite HAART among coinfected drug users (DUs) compared to HCV-monoinfected DUs, providing further support that HIV accelerates liver disease in the HAART era [36].

Hepatic steatosis (HS), a common (40\%-75\%) complication of HCV monoinfection and HCV/HIV co-infection, is associated with rapid fibrosis progression [37], although a recent meta-analysis found that it is not necessarily more common in co-infected than $\mathrm{HCV}$ monoinfected patients [38]. HS is associated with increased body mass index, diabetes, elevated ALT levels, HCV genotype 3, necroinflammation, and fibrosis [37, 38].

\section{Pathogenesis of Liver Disease in Co-infection}

Mechanisms to explain accelerated liver disease in coinfected patients are not well understood but may include direct viral effects and immunologic alterations such as immune activation, apoptosis, and diminished HCVspecific T-cell responses (Table 1) [16-18]. Immune activation by HIV induces cytokine changes (eg, IL-4, IL5 , and IL-13, TGF- $\beta$ ) that increase liver inflammation and fibrosis [17, 18]. Coinfection increases apoptosis of hepatocytes through a Fas/FasL pathway that could account for accelerated liver disease [17, 18]. Accumulation of cytotoxic CD8 $\mathrm{T}$ cells in the liver that increases inflammatory mediators in co-infected compared to $\mathrm{HCV}$ monoinfected patients may also lead to increased tissue damage in co-infected patients [39, 40]. New evidence shows HIV-specific CD8 T cells accumulate in the liver in co-infection and produce TNF- $\alpha$, which is associated with liver fibrosis [18, 41]. Recently, HIV-related microbial translocation that causes systemic activation has been linked with severity of HCV-related liver disease [42].

Increasing evidence finds HIV replication in hepatocytes and hepatic stellate cells (HSC) [18, 19, 43]. HIV infection of activated HSC promotes collagen expression and secretion of proinflammatory cytokines [43]. In addition to infection, HIV proteins induce hepatocytes to apoptosis and release of inflammatory chemokines and cytokines that promote fibrosis [18, 19]. Further, HIV and HCV co-infection may increase tumor necrosis factor-related apoptosis-inducing ligand (TRAIL)-mediated apoptosis of hepatocytes [17, 18, 44].

Insulin resistance (IR), also common in chronic HCV, appears to be critical in liver steatosis and liver disease progression. A recent study found IR associated with liver fibrosis and steatosis in HCV-monoinfected but not co-infected patients [45], but another study found IR associated with liver fibrosis in co-infected patients [46]. The mechanism for IR in liver disease among $\mathrm{HCV}$-infected patients is unknown, but hyperinsulinemia and hyperglycemia stimulate HSC, leading to increased connective tissue growth factor and accumulation of extracellular matrix [46].

New Technologies for Diagnosis and Staging of Liver Disease

Although liver biopsy is the gold standard for staging liver disease, its invasive nature, serious complications, sampling error, and inherent heterogeneity have prompted research to identify noninvasive methods [10, 21, 47]. Promising methodologies include transient elastography/elastometry (TE) and serologic biomarkers.

TE, which uses ultrasound readings to measure liver elasticity or stiffness, is well tolerated and can accurately stage fibrosis and cirrhosis [35, 47], although discriminating power may be low [48]. TE may also be useful in patients with normal aminotransferase levels [34, 35].

Serological markers correlated with liver fibrosis stage can be classified into three groups: 1) indices from routine blood tests of liver function [eg, APRI (aspartate aminotransferase [AST]-to-platelet ratio index) and Fib-4 (age, AST, platelets, and ALT level)];2) markers of extracellular matrix metabolism (eg, hyaluronic acid); and 3) indices combining markers of both types [49]. These are valid markers of liver fibrosis and predictive of HCV-related liver mortality in monoinfected and co-infected individuals $[49,50]$.

Other promising noninvasive technologies include DNA microarray analysis to identify novel biomarkers to assess fibrosis [51] and MRI to measure steatosis and predict adipose tissue and metabolic factors associated with steatosis in co-infected patients [52].

\section{Other Complications of HIV/HCV Co-infection}

Other Immune Dysregulation and Hematologic Disorders

Although both HCV and HIV activate B cells, their interaction in the lymphoid system needs study [16]. Both 
viruses induce B lymphocytes to synthesize cryoglobulins, but a recent study found only a marginal influence of HIV infection on cryoglobulin production in HCVinfected patients [53]. A large retrospective study found $\mathrm{HCV}$ co-infected patients had lower C-reactive protein (CRP) levels than HIV monoinfected patients, suggesting that HCV decreases the liver's ability to secrete CRP [54]. HIV-associated thrombocytopenia remains an important problem in the HAART era and is associated with cirrhosis but also HCV infection without serious liver disease [55]. This may be an important consideration in staging liver disease using APRI, which is calculated using platelet count.

\section{Kidney Disease}

A meta-analysis of 24 observational studies and clinical trials found that $\mathrm{HCV}$ co-infection is associated with increased HIV-related kidney disease risk, including proteinuria and acute renal failure, compared to HIV monoinfection [56]. A large retrospective study of HIVinfected veterans also found that $\mathrm{HCV}$ co-infection was associated with higher chronic kidney disease rates; HCV prevalence increased with worsening estimated glomerular filtration rate (eGFR) [57]. The largest study of biopsy-proven renal disease found that $\mathrm{HIV} / \mathrm{HCV}$-associated nephropathies reduced survival compared to $\mathrm{HCV}$ monoinfection [58].

\section{Cardiovascular Disease}

$\mathrm{HCV}$ co-infection is associated with a higher prevalence of cardiovascular disease (CVD) than HIV monoinfection. HCV co-infection is associated with increased risk of cerebrovascular disease and a trend toward increased risk of acute myocardial infarction among HIV-infected patients [59]. HIV-infected patients have an increased CVD risk because HAART and HIV-associated chronic inflammation can cause endothelial dysfunction [60]. Circulating soluble cellular adhesion molecules (CAMS) released by the vascular endothelium, including soluble intercellular adhesion molecule-1 (sICAM-1) and vascular adhesion molecule-1 (sVCAM-1), are higher in coinfected patients stably treated with HAART than healthy controls [60]. HAART can lower sICAM-1 and sVCAM1 , suggesting that HAART can improve endothelial cell function and decrease CVD risk by decreasing plasma HIV-RNA levels, increasing T-cell number and function, and decreasing immune activation. Patients with advanced HCV infection have higher levels of SICAM-1 and sVCAM-1, suggesting that $\mathrm{HCV}$ infection also causes endothelial dysfunction, and response to $\mathrm{HCV}$ treatment might reduce CVD risk [60].
Neurologic Status

Both HIV and HCV replicate in the brain and cerebrospinal fluid (CSF) and are implicated in neurocognitive and peripheral neuropathy syndromes [61-64]. Co-infected subjects show significant cognitive-motor impairment compared to HIV-monoinfected patients [63] and higher rates of global cognitive impairment, especially in learning and memory [64]. Recently, HCV RNA and antigens were found in brains of co-infected patients [61]. HCV core protein activates human glia and contributes to HIVassociated neurotoxicity [62]. Plasma lipopolysaccharides (LPS), indicators of microbial translocation from the gut, induce monocyte activation in HIV infection and may contribute to HIV-associated dementia (HAD) by increased trafficking of activated monocytes into the brain [65]. That LPS levels are higher in HCV co-infected patients suggests that HCV may influence HAD pathogenesis [65].

In contrast to findings of increased neurocognitive impairment in co-infected patients, a retrospective study from the AIDS Clinical Trials Group Longitudinal Linked Randomized Trials (ALLRT) found that active HCV infection did not exacerbate clinically significant neurocognitive dysfunction or peripheral neuropathy in individuals with controlled HIV infection [66].

Because sensory neuropathy ( $\mathrm{SN}$ ) is a common complication of HIV infection and certain HIV treatments and is associated with $\mathrm{HCV}$ infection, there are concerns about possible synergistic effects of these viruses on the peripheral nervous system [67]. However, a survey among HIVinfected patients in six international sites found $\mathrm{HCV}$ seropositivity was not associated with increased SN risk [67].

\section{Diabetes Mellitus}

One of the largest prospective studies of HIV-infected persons and uninfected controls found that while HIV infection itself is not associated with increased diabetes mellitus (DM) risk, HCV coinfection is associated with higher risk, with a similar trend in the HIV-uninfected group. Risk was not altered by presence of liver damage as measured by ALT and AST levels [68]. A large prospective study of HIV-infected and uninfected women also found that $\mathrm{HCV}$ infection and higher HCV RNA levels were associated with incident diabetes, suggesting that HCVinfected patients should be screened to diabetes [69].

\section{Bone Complications}

Among the emerging comorbidities in the HAART era are bone complications, including osteonecrosis or osteoporosis, but the role of HCV and HAART is controversial [70]. 
In a national cohort of patients on combination ART, the 10-year incidence of bone fractures was 3.6-fold higher in HCV co-infected patients perhaps because patients with chronic liver disease have decreased bone mass [70]. Active monitoring of co-infected patients is recommended for prevention of bone fractures.

\section{Treatment of HIV in Co-infected Patients}

The timing of initiation of HAART in relation to anti-HCV therapy in co-infected patients poses challenges for clinicians. HAART may slow liver disease progression and might therefore be initiated earlier in co-infected than HIV monoinfected patients $[11,71]$. On the other hand, HAART might increase fibrosis in co-infected patients through cumulative hepatotoxicity [11, 13, 72]. Recent guidelines recommend that HAART generally be initiated first to slow liver disease progression and increase CD4 count, but certain drugs should be avoided (eg, ZDV, didanosine, stavudine, and abacavir) and others should be monitored for hepatoxicity $[32 \bullet \bullet, 73 \bullet \cdot]$. Although ART interruption is deleterious to the HIV-infected population, the first randomized study of ART interruptions in HCV co-infected persons found that interruption was particularly unsafe in co-infected persons because of elevated nonopportunistic disease death, though not liver disease death [74].

\section{Treatment of HCV in Co-infected Patients}

Treatment of chronic HCV in co-infected individuals is a priority because of their more rapid progression to ESLD, poor tolerance of ART, and greater risk of hepatoxicity [75]. Clearance is associated with regression of liver fibrosis and reduced risk of ART hepatoxicity [75, 76]. However, anti-HCV treatment is less effective in coinfected patients [75].

$\mathrm{HCV}$ treatment guidelines for co-infected patients are published [77], but there is a lack of consensus regarding key factors that might inform initiation and duration of therapy, including stage of HIV and HCV disease and viral load, HCV genotype, degree of hepatic fibrosis, and patient's readiness to tolerate and adhere to treatment. These have clinical importance because they influence safety, tolerability, and success of therapy. Investigations continue to identify better predictors of treatment response that could guide the pretreatment evaluation process and permit earlier termination of ineffective treatment, reducing additional cost and adverse effects of ineffective therapy. There are no guidelines for the clinical management and treatment of co-infected children, and the limited experience in their management and lack of evidence base to guide policy is a barrier to achieving optimal care [78].

\section{Current Standard Therapeutic Regimen}

Pegylated interferon plus ribavirin (pegIFN + RBV) is the standard HCV treatment in both monoinfected and coinfected patients [77, 79]. Although guidelines recommend a fixed course of 48 weeks to optimize HCV treatment in co-infected patients [77], a recent study explored responseguided therapy, with duration based on virologic response at treatment weeks 4,12 , and 24 [80]. The results were encouraging, with $55 \%$ achieving a sustained viral response (SVR). Among patients who failed a prior suboptimal treatment regimen, retreatment with pegIFN + RBV for 12 months achieved an SVR in nearly one third, an encouraging outcome in light of earlier studies with lower retreatment response rates [75].

\section{Predictors of Treatment Response}

The best predictors of treatment outcome are virologic response kinetics, including rapid viral response (RVR), defined as HCV viral load below the level of detectability 4 weeks after treatment initiation, early viral response (EVR), defined as undetectable HCV load or a $2 \log$ drop from baseline 12 weeks after therapy initiation, and SVR, defined as undetectable HCV load 24 weeks after therapy completion [81]. While undetectable HCV RNA at week 4 is the best predictor of SVR in co-infected patients, baseline serum HCV RNA is an independent predictor of SVR in HCV genotype 1 patients [82]. Although these predictors use absence of serum HCV RNA as the marker of treatment success, negative-strand HCV RNA in PBMCs in the absence of plasma HCV RNA has been reported [8].

Results of investigations of impact of baseline CD4 count on viral response kinetics are mixed. In a large randomized study of pegIFN + RBV in co-infected patients that included a small number of patients with CD4 counts $<200$ cells $/ \mu \mathrm{L}, \mathrm{SVR}$ rates tended to increase with higher CD4 counts in genotype 1 , but were independent of baseline CD4 counts for genotypes 2/3 [83]. Another large randomized study of co-infected patients found the efficacy of pegIFN + RBV was not different in patients with and without severe immunodeficiency, suggesting that advanced immunosuppression is not a major factor in predicting SVR [84].

In the AIDS Clinical Trials Group (ACTG), HCV quasispecies complexity was an important predictor of treatment outcomes, with lower baseline complexity associated with EVR and a decrease in complexity by 4 weeks associated with RVR [81]. Extrahepatic replication in B, 
CD4, CD8, and NK cells at the end of 48 weeks of treatment has predicted viral relapse and, although the assays are cumbersome, they might identify patients whose treatment should be extended to 72 weeks [85].

\section{Adverse Events Associated with Anti-HCV Therapy}

IFN-related adverse events (AEs), specifically CD4 cell declines and psychiatric effects, are reported to be more common in co-infected virologic responders than nonresponders [86]. Also with successful IFN therapy, alterations in cytokine pools necessary to improve immune function may have negative effects in the brain by traversing the blood-brain barrier [86].

The first meta-analysis of sex difference in AEs in co-infected individuals showed that women were more likely to develop AEs requiring treatment discontinuation or dose modification and to develop them earlier, but the types of AEs were similar [87]. Women on NNRTIs were more likely to discontinue therapy, and women on AZT were more likely to experience AEs, suggesting that in women antiviral regimen is an important predictor of treatment discontinuation and modification.
HAART as HCV Therapeutic Agent

Table 2 summarizes the therapeutic and adverse effects of HAART on HCV disease, alone or in combination with pegIFN + RBV. Early HAART may protect co-infected patients from liver fibrosis progression [71]. HAART can significantly decrease liver HCV necroinflammatory activity in co-infected patients with relatively preserved immune status, possibly by inhibiting HIV replication in the liver or decreasing level of proinflammatory cytokines [71]. In vitro, the HIV protease inhibitor nelfinavir inhibits $\mathrm{HCV}$ replication at concentrations showing no cytotoxicity and acts synergistically with IFN against $\mathrm{HCV}$, suggesting that nelfinavir could improve the antiviral effects of IFN in coinfected patients [88].

Some ART medications, especially abacavir, may compromise the response to anti-HCV therapies, perhaps by competing intracellularly with RBV [89]. However, a large cohort study did not find an association of abacavir or other ARTs with reduced EVR or SVR [90].

The combination of HAART and pegIFN + RBN may also increase the frequency of AEs [13]. HCV therapy with zidovudine (ZDV) has been associated with higher anemia rates [13]. RBV with NRTIs such a didanosine has been

Table 2 Therapeutic and adverse effects on HCV disease of antiretroviral agents alone and in combination with anti-HCV therapy in co-infected individuals

\begin{tabular}{|c|c|c|c|c|}
\hline Therapy & Therapeutic effect & Reference & Adverse event & Reference \\
\hline \multirow[t]{6}{*}{ HAART } & $\downarrow$ HIV replication in liver & {$[71]$} & $\begin{array}{l}\uparrow \text { Liver enzymes (LEE) at HAART } \\
\text { initiation (IRD) }\end{array}$ & [93] \\
\hline & $\downarrow$ Proinflammatory cytokines & {$[39,71]$} & $\uparrow$ Hepatoxicity & {$[13,72]$} \\
\hline & $\downarrow$ Hepatic necroinflammatory activity & {$[71]$} & & \\
\hline & $\downarrow$ Liver necrosis and inflammation & {$[11]$} & & \\
\hline & $\downarrow$ Liver disease progression & {$[11,71]$} & $\begin{array}{l}\uparrow \text { Hepatocellular necrosis } \\
\text { and steatosis }\end{array}$ & {$[13]$} \\
\hline & $\downarrow$ Liver mortality & {$[13]$} & & \\
\hline \multirow[t]{2}{*}{ Protease inhibitors } & $\downarrow$ HCV replication in vitro & {$[88]$} & & \\
\hline & $\downarrow$ Hepatotoxicity after SVR & {$[76]$} & & \\
\hline \multirow[t]{2}{*}{ NRTI } & & & $\uparrow$ Steatosis & {$[11]$} \\
\hline & & & $\uparrow$ Hepatotoxicity after SVR & {$[76]$} \\
\hline Efavirenz & $\downarrow$ Hepatotoxicity after SVR to IFN & {$[76]$} & & \\
\hline \multicolumn{5}{|l|}{ HAART + PegIFN + RBV } \\
\hline ZDV + PegIFN + RBV & & & $\uparrow$ Anemia & {$[13,32 \bullet \bullet]$} \\
\hline \multirow[t]{2}{*}{$\mathrm{PI}+$ pegIFN + RBV } & $\downarrow$ Hepatotoxicity & {$[76]$} & & \\
\hline & $\begin{array}{l}\text { Synergistic } \downarrow \text { HCV replication } \\
\text { in vitro }\end{array}$ & {$[88]$} & & \\
\hline NNRTI + pegIFN + RBV & $\downarrow$ Hepatotoxicity & {$[76]$} & & \\
\hline \multirow[t]{3}{*}{$\mathrm{NRTI}+$ pegIFN + RBV } & & & $\uparrow$ Mitochondrial toxicity & {$[13,32 \bullet \bullet, 91,92]$} \\
\hline & & & $\uparrow$ Steatosis and fibrosis & {$[91,92]$} \\
\hline & & & $\downarrow$ Response to anti-HCV therapies & {$[32 \bullet \bullet, 89]$} \\
\hline
\end{tabular}

HAART highly active antiretroviral therapy; IFN interferon; IRD immune restoration disease; NNRTI nonnucleoside reverse transcriptase inhibitor (efavirenz); NRTI nucleoside reverse transcriptase inhibitor (abacavir, didanosine, stavudine); $P$ egIFN $+R B V$ pegylated interferon + ribavirin; $P I$ protease inhibitor (nelfinavir); $R B V$ ribavirin; $S V R$ sustained viral response to pegIFN + RBV; $Z D V$ zidovudine 
associated with increased risk of mitochondrial toxicity (MT) and worsening steatosis/fibrosis [13, 91, 92]. MT-associated laboratory abnormalities are frequent during pegIFN + RBV therapy in combination with HAART, especially when high RBV doses are used [91]. However, patients with signs of MT show faster decreases in HCV RNA levels and achieve higher SVR rates, probably because MT reflects increased intracellular RBV levels. Clinicians should be aware of potential interactions between NRTIs and RBV in coinfected patients, and increased lactate levels might be useful to adjust RBV dosage to optimal efficacy [91].

Co-infected patients may experience liver enzyme elevation (LEE) following HAART initiation [93]. CD4 Tcell increases early after HAART initiation were higher among co-infected patients who developed LEE than coinfected or monoinfected patients who did not develop LEE, suggesting that LEE early in HAART is a form of immune restoration disease (IRD) or immune reconstitution inflammatory syndrome (IRIS) involving an immune reconstitution-induced inflammatory response to $\mathrm{HCV}$ specific antigens [94]. The risk of LEE after HAART initiation is lower in co-infected patients with SVR to anti$\mathrm{HCV}$ therapy, arguing for HCV treatment before commencing HAART [76]. In contrast, an Italian multicenter study found that HAART is not a risk factor for LEE in coinfected patients and does not modify the association between coinfection and the risk of LEE [95].

\section{Novel New Therapies}

Because pegIFN + RBV leads to successful outcome in only $40 \%$ to $50 \%$ of monoinfected and $30 \%$ of co-infected patients, more effective drugs are being developed [14, 15•]. As in HIV, triple-combination therapies may be more effective in achieving virologic cure and less prone to resistance development in monoinfected and co-infected patients. NS3 protease and NS5B polymerase enzymes, essential for $\mathrm{HCV}$ replication, are primary targets. Results for inhibitors targeting these enzymes (combined with pegIFN + RBV) are positive in clinical trials [11, 96, 97] and preclinical studies [98-100]. The most promising of these are the protease inhibitors telaprevir and boceprevir, which are expected to be approved this year [101, 102]. Taribavirin, an oral RBV prodrug with significantly lower anemia rates, is in phase III trials [103].

\section{Anti-HCV Treatment in Acute HCV Infection}

Increasing acute $\mathrm{HCV}$ infections among HIV-infected populations were reported in Europe in the early 2000s, most due to sexual transmission [4]. Because HIV-infected persons have delayed HCV antibody production, screening with thirdgeneration ELISA tests in the first 6 months is inadequate [104]. A recent study found the median time from $\mathrm{HCV}$ infection to antibody production was 158 days but the median ALT at the first positive PCR was $65 \mathrm{IU} / \mathrm{mL}$, suggesting that elevated ALTs in at-risk patients should indicate HCV testing by PCR to diagnose and treat infection early [104].

Treatment data for acute HCV infection in co-infected patients have emerged only recently, and questions remain regarding optimal time, indication, therapy duration, and whether parallel initiation of HAART is necessary [13]. The Australian Trial in Acute Hepatitis C (ATAHC) found high treatment success after 24 weeks of therapy for both acute and early chronic HCV infections in co-infected patients, with an SVR of $80 \%$ [105]. RVR had a $100 \%$ positive predictive value, suggesting that RVR is an important predictor of SVR in acute and chronic $\mathrm{HCV}$ infection. Results for three patients suggest that an SVR is possible even during primary HIV infection [106].

\section{Conclusions}

HIV-infected patients should be screened regularly for HCV co-infection, particularly if they are in high-risk groups. Sexual transmission of HCV needs to be included in patient counseling both for HIV-infected men and women. Increased progression rates to AIDS and liver disease in co-infected individuals may require earlier and more aggressive treatment of both infections. However, following treatment initiation, patients should be monitored for AEs, with prompt intervention to support continued treatment. For most co-infected patients, HAART should be initiated before anti-HCV therapy to slow liver progression and increase CD4 counts. Promising new therapies available in the near future will increase SVR in co-infected individuals.

Acknowledgment The work of the authors for this review was supported by NIH/NIAID grant 2 R01 AI 052065-05A2.

Disclosure No potential conflicts of interest relevant to this article were reported.

Open Access This article is distributed under the terms of the Creative Commons Attribution Noncommercial License which permits any noncommercial use, distribution, and reproduction in any medium, provided the original author(s) and source are credited.

\section{References}

Papers of particular interest, published recently, have been highlighted as:

- Of importance

•- Of major importance

1. Alter MJ: Epidemiology of viral hepatitis and HIV co-infection. J Hepatol 2006, 44(1 Suppl):S6-9. 
2. Thomas DL and Seeff LB: Natural history of hepatitis C. Clin Liver Dis 2005, 9(3):383-98, vi.

3. Frederick T, Burian P, Terrault N, et al.: Factors associated with prevalent hepatitis $\mathrm{C}$ infection among HIV-infected women with no reported history of injection drug use: the Women's Interagency HIV Study (WIHS). AIDS Patient Care STDS 2009, 23(11):915-23.

4. Tohme RA and Holmberg SD: Is sexual contact a major mode of hepatitis C virus transmission? Hepatology 2010, 52(4):1497-505.

5. van de Laar TJ, Paxton WA, Zorgdrager F, et al.: Sexual Transmission of Hepatitis C Virus in Human Immunodeficiency Virus-Negative Men Who Have Sex With Men: A Series of Case Reports. Sex Transm Dis 2010.

6. Koziel MJ and Peters MG: Viral hepatitis in HIV infection. N Engl J Med 2007, 356(14):1445-54.

7. Soriano V, Mocroft A, Rockstroh J, et al.: Spontaneous viral clearance, viral load, and genotype distribution of hepatitis $\mathrm{C}$ virus $(\mathrm{HCV})$ in $\mathrm{HIV}$-infected patients with anti-HCV antibodies in Europe. J Infect Dis 2008, 198(9):1337-44.

8. Laskus T, Operskalski EA, Radkowski M, et al.: Negative-strand hepatitis $\mathrm{C}$ virus (HCV) RNA in peripheral blood mononuclear cells from anti-HCV-positive/HIV-infected women. J Infect Dis 2007, 195(1):124-33.

9. Moreno S, Garcia-Samaniego J, Moreno A, et al.: Noninvasive diagnosis of liver fibrosis in patients with HIV infection and HCV/HBV co-infection. J Viral Hepat 2009, 16(4):249-58.

10. Castera L: Transient elastography and other noninvasive tests to assess hepatic fibrosis in patients with viral hepatitis. J Viral Hepat 2009, 16(5):300-14.

11. Sulkowski MS: Management of hepatic complications in HIVinfected persons. J Infect Dis 2008, 197 Suppl 3:S279-93.

12. Neukam K, Macias J, Mira JA, and Pineda JA: A review of current anti-HCV treatment regimens and possible future strategies. Expert Opin Pharmacother 2009, 10(3):417-33.

13. Sulkowski MS: Viral hepatitis and HIV coinfection. J Hepatol 2008, 48(2):353-67.

14. Webster DP, Klenerman P, Collier J, and Jeffery KJ: Development of novel treatments for hepatitis C. Lancet Infect Dis 2009, 9(2):108-17.

15. - Franciscus A, (Editor): Hepatitis $\mathrm{C}$ treatments in current clinical development. HCV Advocate 2010. This is an annotated tabulated summary of HCV drugs in clinical development.

16. Rotman $\mathrm{Y}$ and Liang TJ: Coinfection with hepatitis $\mathrm{C}$ virus and human immunodeficiency virus: virological, immunological, and clinical outcomes. J Virol 2009, 83(15):7366-74.

17. Roe B and Hall WW: Cellular and molecular interactions in coinfection with hepatitis $\mathrm{C}$ virus and human immunodeficiency virus. Expert Rev Mol Med 2008, 10:e30.

18. Kim AY and Chung RT: Coinfection with HIV-1 and HCV-a one-two punch. Gastroenterology 2009, 137(3):795-814.

19. Blackard JT and Sherman KE: HCV/ HIV co-infection: time to re-evaluate the role of HIV in the liver? J Viral Hepat 2008, 15 (5):323-30.

20. Martin-Thormeyer EM and Paul RH: Drug abuse and hepatitis C infection as comorbid features of HIV associated neurocognitive disorder: neurocognitive and neuroimaging features. Neuropsychol Rev 2009, 19(2):215-31.

21. Soriano V, Vispo E, Labarga P, et al.: Viral hepatitis and HIV coinfection. Antiviral Res 2010, 85(1):303-15.

22. Chen TY, Ding EL, Seage Iii GR, and Kim AY: Meta-analysis: increased mortality associated with hepatitis $\mathrm{C}$ in HIV-infected persons is unrelated to HIV disease progression. Clin Infect Dis 2009, 49(10):1605-15.

23. d'Arminio Monforte A, Cozzi-Lepri A, Castagna A, et al.: Risk of developing specific AIDS-defining illnesses in patients coinfected with HIV and hepatitis $\mathrm{C}$ virus with or without liver cirrhosis. Clin Infect Dis 2009, 49(4):612-22.
24. - Kovacs A, Karim R, Mack WJ, et al.: Activation of CD8 T cells predicts progression of HIV infection in women coinfected with hepatitis C virus. J Infect Dis 2010, 201(6):823-34. This study showed that HCV-viremic women with HIV co-infection who have high levels of T-cell activation may have increased AIDS risk, and suggested that earlier treatment of HIV and HCV infections may be beneficial.

25. Kovacs A, Al-Harthi L, Christensen S, et al.: CD8(+) T cell activation in women coinfected with human immunodeficiency virus type 1 and hepatitis C virus. J Infect Dis 2008, 197 (10):1402-7.

26. Gonzalez VD, Falconer K, Blom KG, et al.: High levels of chronic immune activation in the T-cell compartments of patients coinfected with hepatitis $\mathrm{C}$ virus and human immunodeficiency virus type 1 and on highly active antiretroviral therapy are reverted by alpha interferon and ribavirin treatment. J Virol 2009, 83(21):11407-11.

27. Korner C, Kramer B, Schulte D, et al.: Effects of HCV coinfection on apoptosis of CD4+ T-cells in HIV-positive patients. Clin Sci (Lond) 2009, 116(12):861-70.

28. Potter M, Odueyungbo A, Yang H, et al.: Impact of hepatitis C viral replication on CD4+ T-lymphocyte progression in HIV$\mathrm{HCV}$ coinfection before and after antiretroviral therapy. AIDS 2010, 24(12):1857-65.

29. Peters L, Mocroft A, Soriano V, et al.: Hepatitis C virus coinfection does not influence the CD4 cell recovery in HIV-1infected patients with maximum virologic suppression. J Acquir Immune Defic Syndr 2009, 50(5):457-63.

30. Yacisin K, Maida I, Rios MJ, et al.: Hepatitis C virus coinfection does not affect CD4 restoration in HIV-infected patients after initiation of antiretroviral therapy. AIDS Res Hum Retroviruses 2008, 24(7):935-40.

31. Al-Harthi L, Voris J, Du W, et al.: Evaluating the impact of hepatitis $\mathrm{C}$ virus (HCV) on highly active antiretroviral therapymediated immune responses in HCV/HIV-coinfected women: role of $\mathrm{HCV}$ on expression of primed/memory T cells. J Infect Dis 2006, 193(9):1202-10.

32. • Panel on Antiretroviral Guidelines for Adults and Adolescents, Guidelines for the use of antiretroviral agents in HIV-1-infected adults and Adolescents. Department of Health and Human Services. 2009. p. 1-161. These are recent US guidelines for antiretroviral therapy in HIV/HCV co-infection.

33. Thein HH, Yi Q, Dore GJ, and Krahn MD: Natural history of hepatitis $\mathrm{C}$ virus infection in HIV-infected individuals and the impact of HIV in the era of highly active antiretroviral therapy: a meta-analysis. AIDS 2008, 22(15):1979-91.

34. Martin-Carbonero L, de Ledinghen V, Moreno A, et al.: Liver fibrosis in patients with chronic hepatitis $\mathrm{C}$ and persistently normal liver enzymes: influence of HIV infection. J Viral Hepat 2009, 16(11):790-5.

35. Maida I, Soriano V, Barreiro P, et al.: Liver fibrosis stage and $\mathrm{HCV}$ genotype distribution in HIV-HCV coinfected patients with persistently normal transaminases. AIDS Res Hum Retroviruses 2007, 23(6):801-4.

36. Smit C, van den Berg C, Geskus R, et al.: Risk of hepatitisrelated mortality increased among hepatitis $\mathrm{C}$ virus/HIV-coinfected drug users compared with drug users infected only with hepatitis C virus: a 20 -year prospective study. J Acquir Immune Defic Syndr 2008, 47(2):221-5.

37. Sterling RK, Contos MJ, Smith PG, et al.: Steatohepatitis: Risk factors and impact on disease severity in human immunodeficiency virus/hepatitis C virus coinfection. Hepatology 2008, 47(4):1118-27.

38. Machado MV, Oliveira AG, and Cortez-Pinto H: Hepatic steatosis in patients coinfected with human immunodeficiency virus/hepatitis $\mathrm{C}$ virus: a meta-analysis of the risk factors. Hepatology 2010, 52(1):71-8. 
39. Kuntzen T, Tural C, Li B, et al.: Intrahepatic mRNA expression in hepatitis $\mathrm{C}$ virus and HIV/hepatitis $\mathrm{C}$ virus co-infection: infiltrating cells, cytokines, and influence of HAART. AIDS 2008, 22(2):203-10.

40. Nakamoto N, Kaplan DE, Coleclough J, et al.: Functional restoration of HCV-specific CD8 T cells by PD-1 blockade is defined by PD-1 expression and compartmentalization. Gastroenterology 2008, 134(7):1927-37, 1937 e1-2

41. Vali B, Yue FY, Jones RB, et al.: HIV-specific T-cells accumulate in the liver in HCV/HIV co-infection. PLoS One 2008, 3(10): e3454.

42. Balagopal A, Philp FH, Astemborski J, et al.: Human immunodeficiency virus-related microbial translocation and progression of hepatitis C. Gastroenterology 2008, 135(1):226-33.

43. Tuyama AC, Hong F, Saiman Y, et al.: Human immunodeficiency virus (HIV)-1 infects human hepatic stellate cells and promotes collagen I and monocyte chemoattractant protein-1 expression: implications for the pathogenesis of HIV/hepatitis C virus-induced liver fibrosis. Hepatology 2010, 52(2):612-22.

44. Jang JY, Shao R-X, Lin W, et al.: HIV increases HCV-induced hepatocyte apoptosis. Journal of Hepatology In Press, Accepted Manuscript.

45. Halfon P, Penaranda G, Carrat F, et al.: Influence of insulin resistance on hepatic fibrosis and steatosis in hepatitis $\mathrm{C}$ virus (HCV) mono-infected compared with HIV-HCV co-infected patients. Aliment Pharmacol Ther 2009, 30(1):61-70.

46. Merchante N, Rivero A, de Los Santos-Gil I, et al.: Insulin resistance is associated with liver stiffness in $\mathrm{HIV} / \mathrm{HCV}$ coinfected patients. Gut 2009, 58(12):1654-60

47. Kirk GD, Astemborski J, Mehta SH, et al.: Assessment of liver fibrosis by transient elastography in persons with hepatitis $\mathrm{C}$ virus infection or HIV-hepatitis $\mathrm{C}$ virus coinfection. Clin Infect Dis 2009, 48(7):963-72.

48. Vergara S, Macias J, Rivero A, et al.: The use of transient elastometry for assessing liver fibrosis in patients with HIV and hepatitis C virus coinfection. Clin Infect Dis 2007, 45(8):96974.

49. Nunes D, Fleming C, Offner G, et al.: Noninvasive markers of liver fibrosis are highly predictive of liver-related death in a cohort of HCV-infected individuals with and without HIV infection. Am J Gastroenterol 2010, 105(6):1346-53.

50. Al-Mohri H, Murphy T, Lu Y, et al.: Evaluating liver fibrosis progression and the impact of antiretroviral therapy in HIV and hepatitis $\mathrm{C}$ coinfection using a noninvasive marker. $\mathrm{J}$ Acquir Immune Defic Syndr 2007, 44(4):463-9.

51. Suzman DL, McLaughlin M, Hu Z, et al.: Identification of novel markers for liver fibrosis in HIV/hepatitis $\mathrm{C}$ virus coinfected individuals using genomics-based approach. AIDS 2008, 22 (12): 1433-9.

52. Ghotb A, Noworolski SM, Madden E, et al.: Adipose tissue and metabolic factors associated with steatosis in HIV/HCV coinfection: histology versus magnetic resonance spectroscopy. J Acquir Immune Defic Syndr 2010.

53. Lapinski TW, Parfieniuk A, Rogalska-Plonska M, et al.: Prevalence of cryoglobulinaemia in hepatitis $\mathrm{C}$ virus- and hepatitis $\mathrm{C}$ virus/human immunodeficiency virus-infected individuals: implications for renal function. Liver Int 2009, 29 (8):1158-61.

54. Reingold J, Wanke C, Kotler D, et al.: Association of HIV infection and $\mathrm{HIV} / \mathrm{HCV}$ coinfection with $\mathrm{C}$-reactive protein levels: the fat redistribution and metabolic change in HIV infection (FRAM) study. J Acquir Immune Defic Syndr 2008, 48(2):142-8.

55. Marks KM, Clarke RM, Bussel JB, et al.: Risk factors for thrombocytopenia in HIV-infected persons in the era of potent antiretroviral therapy. J Acquir Immune Defic Syndr 2009, 52 (5):595-9.

56. Wyatt CM, Malvestutto C, Coca SG, et al.: The impact of hepatitis $\mathrm{C}$ virus coinfection on HIV-related kidney disease: a systematic review and meta-analysis. AIDS 2008, 22(14):1799807.

57. Fischer MJ, Wyatt CM, Gordon K, et al.: Hepatitis $\mathrm{C}$ and the risk of kidney disease and mortality in veterans with HIV. J Acquir Immune Defic Syndr 2010, 53(2):222-6.

58. Izzedine H, Sene D, Cacoub P, et al.: Kidney diseases in HIV/ HCV-co-infected patients. AIDS 2009, 23(10):1219-26.

59. Bedimo R, Westfall AO, Mugavero M, et al.: Hepatitis C virus coinfection and the risk of cardiovascular disease among HIVinfected patients. HIV Med 2010, 11(7):462-8.

60. Castro IF, Micheloud D, Berenguer J, et al.: Hepatitis C virus infection is associated with endothelial dysfunction in HIV/ hepatitis C virus coinfected patients. AIDS 2010.

61. Letendre S, Paulino AD, Rockenstein E, et al.: Pathogenesis of hepatitis $\mathrm{C}$ virus coinfection in the brains of patients infected with HIV. J Infect Dis 2007, 196(3):361-70.

62. Vivithanaporn P, Maingat F, Lin LT, et al.: Hepatitis C virus core protein induces neuroimmune activation and potentiates human immunodeficiency virus-1 neurotoxicity. PLoS One 2010, 5(9).

63. Aronow HA, Weston AJ, Pezeshki BB, and Lazarus TS: Effects of coinfection with HIV and hepatitis $\mathrm{C}$ virus on the nervous system. AIDS Read 2008, 18(1):43-8.

64. Hinkin $\mathrm{CH}$, Castellon SA, Levine AJ, et al.: Neurocognition in individuals co-infected with HIV and hepatitis C. J Addict Dis 2008, 27(2):11-7.

65. Ancuta P, Kamat A, Kunstman KJ, et al.: Microbial translocation is associated with increased monocyte activation and dementia in AIDS patients. PLoS One 2008, 3(6):e2516.

66. Clifford DB, Smurzynski M, Park LS, et al.: Effects of active $\mathrm{HCV}$ replication on neurologic status in HIV RNA virally suppressed patients. Neurology 2009, 73(4):309-14.

67. Cherry CL, Affandi JS, Brew BJ, et al.: Hepatitis C seropositivity is not a risk factor for sensory neuropathy among patients with HIV. Neurology 2010, 74(19):1538-42.

68. Butt AA, McGinnis K, Rodriguez-Barradas MC, et al.: HIV infection and the risk of diabetes mellitus. AIDS 2009, 23 (10): 1227-34

69. Howard AA, Hoover DR, Anastos K, et al.: The effects of opiate use and hepatitis $\mathrm{C}$ virus infection on risk of diabetes mellitus in the Women's Interagency HIV Study. J Acquir Immune Defic Syndr 2010, 54(2):152-9.

70. Collin F, Duval X, Le Moing V, et al.: Ten-year incidence and risk factors of bone fractures in a cohort of treated HIV1-infected adults. AIDS 2009, 23(8):1021-4.

71. Pascual-Pareja JF, Caminoa A, Larrauri C, et al.: HAART is associated with lower hepatic necroinflammatory activity in HIV-hepatitis C virus-coinfected patients with CD4 cell count of more than 350 cells/microl at the time of liver biopsy. AIDS 2009, 23(8):971-5.

72. Moodie EE, Pant Pai N, and Klein MB: Is antiretroviral therapy causing long-term liver damage? A comparative analysis of HIVmono-infected and HIV/hepatitis C co-infected cohorts. PLoS One 2009, 4(2):e4517.

73. •- Thompson MA, Aberg JA, Cahn P, et al.: Antiretroviral treatment of adult HIV infection: 2010 recommendations of the International AIDS Society-USA panel. JAMA 2010, 304 (3):321-33. These are recent US guidelines for antiretroviral therapy in HIV/HCV co-infection.

74. Tedaldi E, Peters L, Neuhaus J, et al.: Opportunistic disease and mortality in patients coinfected with hepatitis $\mathrm{B}$ or $\mathrm{C}$ virus in the strategic management of antiretroviral therapy (SMART) study. Clin Infect Dis 2008, 47(11):1468-75. 
75. Labarga P, Vispo E, Barreiro P, et al.: Rate and predictors of success in the retreatment of chronic hepatitis $\mathrm{C}$ virus in HIV/ hepatitis C Virus coinfected patients with prior nonresponse or relapse. J Acquir Immune Defic Syndr 2010, 53(3):364-8.

76. Labarga P, Soriano V, Vispo ME, et al.: Hepatotoxicity of antiretroviral drugs is reduced after successful treatment of chronic hepatitis C in HIV-infected patients. J Infect Dis 2007, 196(5):670-6.

77. Soriano V, Puoti M, Sulkowski M, et al.: Care of patients coinfected with HIV and hepatitis C virus: 2007 updated recommendations from the HCV-HIV International Panel. AIDS 2007, 21(9):1073-89.

78. England K, Thorne C, Pembrey L, and Newell ML: Policies and practices for the clinical management of $\mathrm{HIV} / \mathrm{HCV}$ coinfected children in Europe: an epidemiological survey. Eur J Pediatr 2009, 168(8):915-7.

79. Iorio A, Marchesini E, Awad T, and Gluud LL: Antiviral treatment for chronic hepatitis $\mathrm{C}$ in patients with human immunodeficiency virus. Cochrane Database Syst Rev 2010, (1):CD004888.

80. Van den Eynde E, Crespo M, Esteban JI, et al.: Response-guided therapy for chronic hepatitis $\mathrm{C}$ virus infection in patients coinfected with HIV: a pilot trial. Clin Infect Dis 2009, 48 (8):1152-9.

81. Sherman KE, Rouster SD, Stanford S, et al.: Hepatitis C virus (HCV) quasispecies complexity and selection in HCV/HIVcoinfected subjects treated with interferon-based regimens. J Infect Dis 2010, 201(5):712-9.

82. Martin-Carbonero L, Nunez M, Marino A, et al.: Undetectable hepatitis C virus RNA at week 4 as predictor of sustained virological response in HIV patients with chronic hepatitis C. AIDS 2008, 22(1):15-21.

83. Opravil M, Sasadeusz J, Cooper DA, et al.: Effect of baseline CD4 cell count on the efficacy and safety of peginterferon Alfa2a (40KD) plus ribavirin in patients with HIV/hepatitis $\mathrm{C}$ virus coinfection. J Acquir Immune Defic Syndr 2008, 47(1):36-49.

84. Mira JA, Gutierrez-Valencia A, Gil Ide L, et al.: Efficacy and safety of pegylated interferon plus ribavirin in HIV and hepatitis $\mathrm{C}$ virus-coinfected patients with advanced immunosuppression. Clin Infect Dis 2009, 49(8):e84-91.

85. de Felipe B, Leal M, Soriano-Sarabia N, et al.: HCV RNA in peripheral blood cell subsets in HCV-HIV coinfected patients at the end of PegIFN/RBV treatment is associated with virologic relapse. J Viral Hepat 2009, 16(1):21-7.

86. Osinusi A, Rasimas JJ, Bishop R, et al.: HIV/Hepatitis C viruscoinfected virologic responders to pegylated interferon and ribavirin therapy more frequently incur interferon-related adverse events than nonresponders do. J Acquir Immune Defic Syndr 2010, 53(3):357-63.

87. Bhattacharya D, Umbleja T, Carrat F, et al.: Women experience higher rates of adverse events during hepatitis $\mathrm{C}$ virus therapy in HIV infection: a meta-analysis. J Acquir Immune Defic Syndr 2010.

88. Toma S, Yamashiro T, Arakaki S, et al.: Inhibition of intracellular hepatitis $\mathrm{C}$ virus replication by nelfinavir and synergistic effect with interferon-alpha. J Viral Hepat 2009, 16(7):506-12.

89. Vispo E, Barreiro P, Pineda JA, et al.: Low response to pegylated interferon plus ribavirin in HIV-infected patients with chronic hepatitis C treated with abacavir. Antivir Ther 2008, 13(3):429-37.

90. Amorosa VK, Slim J, Mounzer K, et al.: The influence of abacavir and other antiretroviral agents on virological response to HCV therapy among antiretroviral-treated HIV-infected patients. Antivir Ther 2010, 15(1):91-9.

91. Reiberger T, Kosi L, Maresch J, et al.: Mitochondrial toxicity is associated with virological response in patients with HIV and hepatitis $\mathrm{C}$ virus coinfection treated with ribavirin and highly active antiretroviral therapy. J Infect Dis 2010, 202(1):156-60.

92. Bani-Sadr F, Lapidus N, Bedossa P, et al.: Progression of fibrosis in HIV and hepatitis $\mathrm{C}$ virus-coinfected patients treated with interferon plus ribavirin-based therapy: analysis of risk factors. Clin Infect Dis 2008, 46(5):768-74.

93. Price P, Murdoch DM, Agarwal U, et al.: Immune restoration diseases reflect diverse immunopathological mechanisms. Clin Microbiol Rev 2009, 22(4):651-63.

94. Ofotokun I, Smithson SE, Lu C, et al.: Liver enzymes elevation and immune reconstitution among treatment-naive HIV-infected patients instituting antiretroviral therapy. Am J Med Sci 2007, 334(5):334-41.

95. Cicconi P, Cozzi-Lepri A, Phillips A, et al.: Is the increased risk of liver enzyme elevation in patients co-infected with HIV and hepatitis virus greater in those taking antiretroviral therapy? AIDS 2007, 21(5):599-606.

96. Pockros PJ, Nelson D, Godofsky E, et al.: R1626 plus peginterferon Alfa-2a provides potent suppression of hepatitis $\mathrm{C}$ virus RNA and significant antiviral synergy in combination with ribavirin. Hepatology 2008, 48(2):385-97.

97. Roberts SK, Cooksley G, Dore GJ, et al.: Robust antiviral activity of R1626, a novel nucleoside analog: a randomized, placebo-controlled study in patients with chronic hepatitis $\mathrm{C}$. Hepatology 2008, 48(2):398-406.

98. Shi ST, Herlihy KJ, Graham JP, et al.: Preclinical characterization of PF-00868554, a potent nonnucleoside inhibitor of the hepatitis C virus RNA-dependent RNA polymerase. Antimicrob Agents Chemother 2009, 53(6):2544-52.

99. Venkatraman S, Velazquez $\mathrm{F}, \mathrm{Wu} \mathrm{W}$, et al.: Discovery and structure-activity relationship of P1-P3 ketoamide derived macrocyclic inhibitors of hepatitis C virus NS3 protease. J Med Chem 2009, 52(2):336-46.

100. Li H, Tatlock J, Linton A, et al.: Discovery of (R)-6-cyclopentyl6-(2-(2,6-diethylpyridin-4-yl)ethyl)-3-((5,7-dimethyl-[1 ,2,4]triazolo[1,5-a]pyrimidin-2-yl)methyl)-4-hydroxy-5,6-dihydropyran2-on e (PF-00868554) as a potent and orally available hepatitis C virus polymerase inhibitor. J Med Chem 2009, 52(5):1255-8.

101. Rodriguez-Torres M: On the cusp of change: new therapeutic modalities for HCV. Ann Hepatol 2010, 9 Suppl:123-31.

102. Fowell AJ and Nash KL: Telaprevir: a new hope in the treatment of chronic hepatitis C? Adv Ther 2010, 27(8):512-22.

103. Poordad F, Lawitz E, Shiffman ML, et al.: Virologic response rates of weight-based taribavirin versus ribavirin in treatmentnaive patients with genotype 1 chronic hepatitis C. Hepatology 2010, 52(4):1208-15.

104. Thomson EC, Nastouli E, Main J, et al.: Delayed anti-HCV antibody response in HIV-positive men acutely infected with HCV. AIDS 2009, 23(1):89-93.

105. Matthews GV, Hellard M, Haber P, et al.: Characteristics and treatment outcomes among HIV-infected individuals in the Australian Trial in Acute Hepatitis C. Clin Infect Dis 2009, 48 (5):650-8.

106. Schulze Zur Wiesch J, Pieper D, Stahmer I, et al.: Sustained virological response after early antiviral treatment of acute hepatitis C virus and HIV coinfection. Clin Infect Dis 2009, 49 (3):466-72. 